António [Manoel de Oliveira] Guterres (Lisboa, 30-IV-1949), próximo Secretario general de Naciones Unidas a partir de 1-I-2017, elegido por aclamación del 13 de octubre de 2016, era presidente de la Internacional socialista cuando escribió el texto que presentamos, incluido como epílogo al libro Tender puentes. PSOE y mundo cristiano (Bilbao 2001), coeditado por Desclée de Brouwer y la Fundación Pablo Iglesias a cargo de Ramón Jáuregui Atondo y Carlos García de Andoin Martín.

Guterres es ingeniero físico y electrónico y había sido secretario general del partido social ista portugués desde 1992 y presidente del Gobierno de Portugal (1995-2002). Cuando dimitió de su cargo, volvió al ejercicio del voluntariado con los más desfavorecidos. Fue sucesivamente vicepresidente (1992-1999) y presidente (1999-2005) de la Internacional socialista y entre junio de 2005 y diciembre de 2015 ha sido Alto Comisario de Naciones Unidas para los Refugiados (ACNUR).

Guterres se ha destacado por su compromiso con los más desfavorecidos y empobrecidos desde su etapa como militante católico comprometido durante las inundaciones que en noviembre de 1967 provocaron alrededor de 300 muertos en las chabolas de Lisboa. Al conocer que el Consejo de Seguridad había acordado su nombramiento declaró que necesitaba "humildad para las difíciles tareas y servir a los más vulnerables, a las víctimas de la guerra, del terrorismo, de las violaciones de los derechos humanos", con la misma lógica que unas semanas antes (abril de 2016) había dicho que las causas de las guerras, de la pobreza, la desigualdad, la violación de los derechos humanos y la degradación medioambiental están cada vez más vinculadas. Para Guterres tan cierto es que la llegada de refugiados e inmigrantes a Europa es minúscula y ciertamente no constituye un peligro, como que las imágenes difundidas nos han hecho percibir una impresión de pánico y de invasión incontrolada que también ha de evitarse.

Este texto, facilitado en su día por mediación de José María Cabral S.I., fue firmado tan sólo tres semanas después de los atentados contra el Pentágono y el WTC de Nueva York, como epílogo al libro citado, referido al diálogo entre el movimiento socialista y el mundo cristiano, pero puede hoy leerse también como una invitación al diálogo interreligioso: Necesitamos, pues, muchos puentes. 


\section{Los puentes con el mundo cristiano}

\section{António Guterres}

La historia del movimiento socialista democrático nos demuestra que hay raíces múltiples en sus orígenes y en su afirmación emancipadora. La tradición clásica y judeocristiana, los valores humanistas y de la llustración, la herencia de las revoluciones inglesa, americana y francesa, los movimientos sindical y cooperativo, las influencias del socialismo utópico, libertario y científico, la convergencia entre el republicanismo liberal y el movimiento socialista y laborista, o entre reformismo y radicalismo, el surgimiento del modelo social-demócrata y socialista democrático, constituyen un acervo común del socialismo democrático europeo contemporáneo, que interesa profundizar en la actualidad. No obstante, en el marco de una vocación universalista, el socialismo democrático se abre en el mundo, cada vez más, a nuevas influencias y a nuevos valores.

Fieles a los principios de la autonomía individual, de la razón y de la solidaridad, continuamos ante la exigencia de conciliar permanentemente libertad e igualdad, como caras de la misma moneda. Es por ello por lo que estamos llamados a perfeccionar nuestros proyectos, aproximándolos a las personas concretas y creando síntesis reformadoras, aptas para armonizar en la práctica, libertad emancipadora y solidaridad voluntaria, igualdad y diferenciación positiva, primado de la ley y regulación económica y social, autonomía y cohesión social. Además, las nuevas generaciones han estado muy marcadas por la fórmula innovadora del programa de Bad-Godesberg del SPD de 1959, en el que se afirmaba expresamente que el socialismo democrático "encuentra sus raíces en la ética cristiana, en el humanismo y en la filosofía clásica", no pretendiendo proclamar verdades últimas, "no por incomprensión o por indiferencia ante las filosofías o las verdades religiosas, sino por respeto a las decisiones del hombre en materia de fe, decisiones cuyo contenido no debe ser determinado ni por un partido político, ni por el Estado. El Partido Social-Demócrata es el partido de la libertad de espíritu".

Después de 1989, con la caída del muro de Berlín y el final de la guerra fría, hubo quien precipitadamente vio una crisis anunciada para el socialismo democrático. Pero, por el contrario, se asistió a una nueva oportunidad para una síntesis fecunda entre la regulación y el mercado, entre el Estado de derecho y la autonomía cívica, entre emancipación y solidaridad. Este es el punto en el que nos encontramos. Y si es 
cierto que el concepto de Estado laico es el que anima las sociedades democráticas, no es menos verdad que el diálogo con y entre las religiones aparece cada vez más como un factor positivo de cohesión y de enriquecimiento de las sociedades en que vivimos. Ese diálogo y esa comprensión constituyen, en nuestros días, un poderoso antídoto contra todos los fundamentalismos y un factor positivo de tolerancia y de respeto mutuo. De ahí que asumamos la vocación universalista de los derechos fundamentales y la fuerza creadora del diálogo entre culturas diferentes.

En el Concilio Vaticano II, la Iglesia Católica afirmó con especial fuerza y determinación esta voluntad de diálogo y de compromiso con la libertad. A la luz de la fidelidad al valor de la dignidad humana debemos tender puentes entre el socialismo democrático y el mundo cristiano, dentro de una lógica de pluralismo y de encuentro solidario de buena voluntad. Y si la igualdad entre todos es un distintivo cristiano, no podemos olvidar que es también el primer distintivo de nuestra tradición política. Después de los trágicos acontecimientos del 11 de septiembre de 2001, el diálogo con las religiones se ha hecho aún más importante. El fanatismo y la intolerancia sólo se contrarrestan con apertura y libertad de espíritu, con cooperación y cultura de paz. Necesitamos, pues, muchos puentes.

Lisboa, 4 de octubre de 2001

(Traduccion del original portugues de Eduardo J. ALONSO Romo, Universidad literaria de Salamanca) 